DOI: 10.2478/v10141-009-0040-y

\title{
Olympism in the Context of Modernity ${ }^{1}$
}

\author{
Zbigniew Dziubiński
}

Josef Pilsudski University of Physical Education in Warsaw, Poland

ABSTRACT

The sociological outlook on Olympism and sport contained in this paper covered the ideas and notions of sport to a lesser extent than the actual state of affairs, that is, the condition of sport here and now. The sociological description of sport assumed that sport was an element of the modern society and contemporary culture. This perspective allowed the description and analysis of sport in terms which are employed by sociology, or more generally, by social sciences. This means that it was possible to reflect upon sport through paradigms, theories and trends of thought which are effectively used in attempts at sociological descriptions of modern societies.

The critical analysis of Olympism and contemporary sport, presented above, does not assert that Olympism and sport have run out of possibilities for further development. On the contrary, both Olympism and contemporary sport are the hope and the chance that a better future awaits communities, cultures, civilizations and humanity on a global scale. Furthermore, the threats and negative trends which emerge in sport should not remain concealed or underestimated, because they are of an objective character and have an effect on the whole of the humanistic power of sport. One should also realise that all the aforementioned negative phenomena and processes do not result from some kind of degeneration of sport as such, but are caused by general, external tendencies which penetrate sport through economic, financial, axiological, ethical and many other channels.

The more or less clear outline of the future of sport contained in this paper is of an alternative and exclusively probabilistic character. The future development of sport can take three different directions. Firstly, the future may bring out and strengthen all the tendencies which are already present in contemporary sport, such as dehumanisation, commercialisation, visualisation and medialisation. Secondly, there may emerge a global trend to force sport into the idealised frame of the past and make it become what it was after its foundations had been laid during the Hellenistic period, or rather, the way people remember it being. However, such inclinations towards general reconstruction usually emerge after radical developments which, for example, challenge sport as a cultural reality. Thirdly, the postmodernist ideals may be revived in one form or another, and while they will not necessarily alter the structure of sport, they will put the emphasis which results from certain trends and processes on some unspecified areas of sport consumption and the pursuit of maximal sensations and excitement in sport.

\footnotetext{
${ }^{1}$ This paper was written as part of the University of Physical Education's statutory research (subject 118) financed by the Ministry of Science and Higher Education.
} 
No ideals are immune to distortion when subjected to the process of materialisation. Ideals are not realised by perfect and metaphysical beings, but by humans made of flesh and bones and having both good and bad inclinations. Every person is socialised and moulded in a specific cultural and social reality which is never free from deviation and pathology. Similarly, there can be no sport, and that includes the Olympic movement, which could possibly remain an enclave of good and nobleness, a paradise on Earth, with a wall separating it from all the phenomena and processes that take place in contemporary societies. In a way, sport and the Olympic movement are bound to be penetrated by diverse phenomena and trends which have an impact on the spirit and image of sport.

There are no ideal societies nor is there ideal sport, free from deviation and pathology. It is thus totally impossible to accomplish the utopia of the Olympic movement and sport as a land of happy people, uninfluenced by phenomena and processes which are characteristic of modern societies. There can be no world without individuals who breach cultural models, norms and values, no world without deviants and swindlers. Nevertheless, this unattainable utopia has to be pursued, because in the pursuit, people can achieve a lot to improve the axionormative order in sport as well as social life in all its aspects.

sport, Olympism, modernity

When we look back at the rise of cultures and societies, we can easily notice that throughout its history, mankind has been engaged in a special type of activity which the English christened "sport" in the 16th century. The role and significance of sport have varied historically. Sometimes, the pendulum swung towards a greater presence of sport in societies and cultures, at other times it swung the opposite way, which meant that the position of sport has been changing in a vertical system with its vector pointing downwards.

All known communities, societies, cultures and civilizations have had some form of sport. Over 6,000 of these forms were compiled, named and described in the World Sports Encyclopedia (Lipoński 2001). This confirms the assertion that sport is an important constituent of every culture, or to put it differently, it was sport, or play, that laid the foundations for the rise and development of cultures (Huizinga 1985).

The genesis of contemporary Olympism is closely linked to Pierre de Coubertin and his idea to revive the Greek legend which dated back to Antiquity. Aside from outstanding intellectual achievements, which in philosophy were endorsed by such great thinkers like Plato, Aristotle and Socrates, the Ancient times went down in history with sport agon that took on the organised form of the Olympics (Lipiec 2007).

In one of its meanings, modern Olympism can be understood as a modern humanistic idea based on and inspired by the idealised Greek prototype of sport, seen as an extremely important element of the culture of ancient Greece, complementary to its other components such as art, philosophy, myths, religion, tradition and festivities. Olympism can also be understood as the materialisation of modern humanistic ideals through the Hellenistic tradition, which has been revived in the organisation of the Olympic Games, a sports celebration for young people around the world (Zuchora 1996).

Olympism was born in Europe under special social and political circumstances. It all happened almost a century after the French Revolution, which had overthrown absolute monarchy and put an end to the estate system. The revolution had been a shocking and educational experience which remodelled the European identity completely. It exposed the spontaneity of social processes and 
showed how easily they could get out of hand. It also questioned the voluntaristic nature of such processes. The French Revolution proved that the abolition of privileges of birth could not eliminate differences and inequality and that even the most profound political system transformation was unable to eliminate all social problems.

Olympism emerged in the times of the industrial revolution, which was a major upsurge in the industrialisation rate. The industrial revolution brought about a radical change in the traditional lifestyle of large human communities which from economies based on agriculture and household labour transformed into ones based on industrial labour in factories. The intensified urbanisation not only prompted a change in space, it first of all ruined the traditional social structure, the system of contacts, interpersonal communication, the pace of life and the social order which had used to be an axionormative one. The industrial revolution not only gave birth to industrial society, it also ignited a serious social issue (Krawczyk 1997).

Olympism was born in an atmosphere of extensive social and cultural transformations, an atmosphere of disintegration of traditional bonds when people felt uprooted and lost as they performed superhuman work under conditions which defied hygiene. The founder of Olympism conceived it as a brand new, global movement based on universal values which would spread over all humanity and become a force to humanise and personalise the relations between individuals, communities, ethnic groups, nations, cultures and civilizations (Żukowska 1996).

The whole of the 20th century showed that despite numerous difficulties and obstacles, such as military conflicts, mass genocide and other bestial acts against various nations, the ideals never ceased to advance and became an undeniable success, the testimony to which is the fact that almost all countries of the world are members of the Olympic movement. The Olympic project, which involves building relations between nations and a harmonious development of individuals, has proved to be very adequate and flexible enough to be accepted by political and social formations, both traditional and modern alike, as well as those which increasingly succumb to the postmodernist logic: consumerism, pursuit of excitement and resignation from acknowledging labour as the core of the life of every human being (Lipiec 1999).

Olympism was born in a modern society and its entire history is linked to modern societies. Consequently, diverse phenomena and processes which occur in modern societies have been there in sport as well, and sometimes they are actually even more prominent in sport. Two of the processes, modernisation and globalisation, are particularly noteworthy, as we can see their impact on sport with the naked eye.

To sociologists, the most interesting approach to sport is the analytical one. They want to know what is so special about this social movement that for over a century has been thriving and systematically extending its global impact and importance, in spite of the antagonists who profess that Olympism has run out of steam. Sociologist August Comte (1973) postulated the following characteristic features of Olympism and sport in general: firstly, a majority of Olympic and sport organizations are based in urban areas; secondly, the organizations are efficiency- and profit-oriented; thirdly, sports training and competition make use of science and technology; fourthly, overt and covert antagonism emerges between different interest groups; fifthly, contemporary sport manifests escalating social contrasts and inequalities; and sixthly, it is an economic system based on individual enterprise and market competition. This all reveals an economic aspect that involves constant pursuit of profit by conducting rational business in the domain of sport (Kosiewicz 2007).

Sport plays a significant role in modern societies and is the arena of diverse processes, such as reorientation towards economics. With that in mind, it is worth watching these processes, which are 
interesting in their own right, but at the same time it is essential to inquire what the processes are really about, what they affect and how they reflect on the public image of sport. The point is also to analyse sport as part of modern societies and to identify all the phenomena and processes which occur in sport. This is to be achieved with all sorts of paradigms, theories and ways of exploring reality which are characteristic of social sciences.

With the above outline of the problem, we shall investigate two trends which emerge as a result of transformations in sport, namely, we will try to show sport with reference to transformations which take place in it, often as a result of external factors, and which are bound with a critical outlook on contemporary sport. We shall also ponder sport in the context of the twilight of the organization of sport on the principles of modernity and headed for some very vague sports hyperreality which is governed by images, spectacle, vision, an interplay of signs and, consequently, chaotic impressions and fantasies (Pawłucki 2003).

In order to fully examine the trends described above, we will use the Marxist bias, the classic vision of Gemeinschaft and Gesellschaft, the ideal model of bureaucracy, the anomy concept, the theory of imperialism, the dependence theory and others. The theories and research perspectives are endorsed by scholars such as R. Dahrendorf, P. Drucker, E. Durkheim, E. Fromm, F. Fukuyama, A. Giddens, S. Huntington, K. Marks, R. Merton, F. Tönnies, M. Weber and others.

\section{A criticism of the modern dimension of sport}

Over a century has passed since the rise of Olympic sports, and it has been a time of spectacular success for the movement, a time of optimism and progress and a time of relishing in sport which is pervaded by typically modern ideas. This enormous enthusiasm arose from faith in progress, the power of the mind, technology, science, the conquest of nature and man's boundless capability to make his mark in all spheres of natural and social life.

Still, just like modernity, sport, revived and developed by modern societies, has undergone transformations and is no longer the same as it was over a century ago, because it simply cannot be. Even more so, it cannot be the same as the idealised sport of ancient Greece. Let us then follow through the major tendencies in the transformation of contemporary sport, as seen from the angle of diverse premises and theories employed by social sciences.

\section{Money and degradation of humans}

In his romantic and idealised vision of man, Karl Marx (1966) asserted that people were free, creative and pro-social beings by nature. One could thus say that in their archetypal state, untouched by culture and civilization, people are naturally predestined to live in communities and act to enrich the natural and social reality around them. However, various disadvantageous social, political and economic conditions exert a negative influence on humans who as a consequence lose their natural characteristics and become incorporated as virtually meaningless cogs in the works of the immense machine of economics. They morph into reified, dependent, enslaved and exploited tools of the system.

Marx linked this situation to modern capitalism, the history of which directly affects modern Olympism. Admittedly, for a long time Olympism resisted ideas characteristic of the capitalist economy, for example by keeping a clear distinction between amateur and professional athletes, but the dawning of the era of Juan Antonio Samaranch undermined the traditional foundations of the 
Olympic movement and the new Olympic society opened for professional sport, complete with huge economic capital.

Although it was never openly said, the International Olympic Committee embraced economy and economics as some of the most important areas of its operations. Ever since that time, the involvement of international corporations in the Olympic Games and sales of broadcast rights to Olympic events have excited the global public just as though it was the most important aspect of the Olympic movement.

In this situation, athletes, as employees, have lost control over the process of their own work and the future of the products of their work. Incorporated into the sports marketing machine, athletes have become an attractive commodity. In a way, they now experience alienation through sport, because their nature has been negated and they have become dehumanised. Instead of fulfilling themselves in creative and unconstrained play, they are subjected to a process of painstaking labour aimed at success. The process extends beyond training and comprises a deep-laid schedule of competitions. Under this logic of sport, people, caught up in the machine of business and economic profits, become a means of pursuing financial benefit, spectatorship, media coverage and political and other values.

These problems drew the attention of Erich Fromm (1963), who strongly underlined the negative influence of the capitalist mechanism on the personal development of human beings. If we apply the logic of Fromm's reasoning to sport, we can say that sport nowadays tends to replace the natural human aspiration "to be" with a struggle "to have". This is a highly alarming phenomenon; however, it does not originate from within sport, but is a result of the presence of sport in modern societies, or capitalism, the mechanisms of which affect, without exceptions, all areas of life, including sport and the Olympic movement.

We thus realise that the battle to preserve the purity of sport has been irrevocably lost and some of the best athletes have paid for it with widely publicised disqualifications. As a matter of fact, this struggle was doomed right from the start, because it is an impossible task to protect an enclave of distinctiveness that does not fit in with the surrounding world in any way.

Community or neo-tribe?

When de Coubertin was preparing his Olympic project, one of his primary goals was to build a community of nations living in peace and friendship and working together for the well-being of all. These beautiful ideals, which have developed institutionally for over a century, are still appealing and highly desirable in a world dominated by modern societies.

While tackling the issue of the Olympic community, let us refer to concepts developed by Ferdinand Tönnies (1975), who distinguished between two types of social groups, namely, Gemeinschaft and Gesellschaft, depending on the kind of social bonds between their members. According to the German sociologist, social relations and associations are determined by human will. There are two kinds of will, essential and arbitrary, where essential will is related to emotions and derived from inner needs, while arbitrary will and the actions it prompts are targeted at achieving external goals.

When we apply the above concept to the analysis of sport, we are inclined to regard the sporting community as a society rather than an actual community, even though people of sport are often referred to as a community, in the popular meaning of the word: "a community of shared ideals". However, the sport community cannot be considered a real community, because it lacks features 
which are characteristic of Gemeinschaft (community). To begin with, the bonds between people of sport are not based on kinship, brotherhood and neighbourhood, but contracts and cold calculation. Secondly, the relations between members of the sporting community are not of a personal character, but businesslike. This means that in sport, we deal with relations such as competitor-competitor, coach-competitor, competitor-referee, sport club president-coach, physician-competitor, etc. These are classic relations between social roles, relations which prioritise the accomplishment of external goals, such as winning an Olympic medal. Thirdly, the methods of social control are not rooted in any tradition, the way it happens in traditional local communities, but they are based on formalised laws. This means that various regulations, terms and conditions, statutes and codes determine how people of sport should behave and this formal control is always deliberate. The behaviour of athletes is supervised by a large group of referees and specialised, formal organisations which seek to ensure that competitors observe all current norms at different training stages and during competitions. Fourthly, in their attitudes, members of the sporting community are guided by the expectations of the public to a greater extent than by autotelic motivations. Success in sport is only meaningful and regarded as true success when the public thinks so, when the society attributes a social and cultural meaning to it. Fifthly, rather than the well-being of sport in its global dimension, participants in sport care more about particularistic reasons. Very few athletes think of the consolidation of sporting institutions and the rise and development of sport when they enter competitions, because they are more focused on the financial aspect of success, prestige, media attention and so on (Tönnies 1975).

The above analysis allows the conclusion that like in modern societies, the importance of traditional communities in sport is in decline, giving way to groupings which Tönnies refers to as Gesellschaft (society). Actually, a more fitting term to refer to the Olympic community is neo-tribe (Maffesoli 1996), which can be interpreted as a group of people who often inhabit different parts of the world and whose shared sense of identity is not a consequence of socialising and spending time together, but predominantly results from common or similar interests, shared Olympic ideals and similar ways of experiencing the interests and ideals.

Citing the British historian B. Anderson (1997), we can also regard the Olympic community as an imaginary community which has been constructed ideologically and which people have believed in without any solid, realistic evidence. A process like this can occur through faith in the common roots of Olympism, common ancestors who competed in ancient Olympic Games, their heroic accomplishments, special vocation and divine endowment.

\section{Extreme rationality}

In his criticism of social organisation, Max Weber (2002) remarked that the organisation introduced extreme rationality, efficiency and instrumentality which locked up societies in "iron cages" and deprived them of spontaneity and freedom. This form of social organization was named the ideal type of bureaucracy. In Weber's understanding, the Olympic movement can be regarded as a classic bureaucratic organisation, because it manifests all features which are characteristic of this type of bureaucracy. Firstly, all forms of conduct are defined by legal norms and regulations. All participants of the sporting life know exactly what they are supposed to do, their activities and responsibilities are precisely defined. The responsibilities are different for a competitor, a coach, a referee and so on. Secondly, the Olympic movement is structured hierarchically and its regulations precisely define the relations of superiority and subordination. Thirdly, most relations in the Olympic movement are of impersonal character and leave little or no room for whims and lawlessness. Diversion of any kind often leads to disqualification and exclusion. Participants of sport are professionals and take positions according to their competence, as confirmed by certificates and 
medals. They advance in the hierarchy following the rules that govern the system. A good example is the career of an athlete who, abiding by precisely defined procedures, records improved results, advances from class to class and wins medals, from a school competition all the way to a gold medal at the Olympic Games. Fourthly, athletes, coaches, referees and others are hired employees, none of whom actually owns a sporting organisation. Fifthly, communication and exchange of information are handled by means of official, written correspondence. There are rules for everything, for example, only selected organisations - national Olympic committees - have the right to enter a national team in the Olympic Games. All athletes entered in Olympic events have to meet certain criteria, for example they have to be citizens of a given country, meet the minimum Olympic requirements and so on. The organisations which enter athletes have to use special forms and submit them by precisely defined deadlines. Sixthly, the Olympic movement and sport in general have their own memory, comprising numerous museums, libraries and archives which store names, scores and descriptions of sport events (Weber 1975).

While appreciating the efficiency and rationality of bureaucracy, crucial for efficient functioning of the Olympic movement, we cannot help but notice a number of threats inherent in it. In the bureaucratic machine of the Olympic movement, athletes lose their personalities and become insignificant elements of a soulless, commercial spectacle. In a long run, the bureaucracy of the Olympic movement dehumanises relations in sport and, consequently, degrades athletes.

The bureaucracy of the Olympic movement, which takes from the Enlightenment a faith in efficiency, calculation and the power of the mind, focuses on efficient action and the multifaceted final success. Somewhere on the way, however, it forgets about the athlete, who now is an important, but clearly not the most important component of this machine.

\section{Anomy and deviation}

Unlike Marx and Tönnies, Émile Durkheim (2000) looked at the dark side of the human nature and pointed out the egoistic and anti-social inclinations of people. According to him, as soon as people realise they can deviate from some socially and culturally accepted paths in order to achieve various particularistic goals, they will do so and that is what commonly happens. The result is anomy and axionormative chaos where moral guidance disappears and the terms of good and evil become blurred.

The phenomena of anomy and deviation, which to a greater or lesser extent occur in modern societies, are also there in sport, the Olympic movement being no exception. A good example here are prohibited drugs and other means used in various fashions to "take shortcuts" and achieve goals in sport. This problem was discussed at length by Robert Merton (1996), who investigated how certain social structures exerted pressure on some individuals in a given society by inducing them to manifest non-conformist attitudes, that is, behaviour which contravened the normative order of the society. When applied to the analysis of sport, this theory helps explain a lot of alarming phenomena and processes which occur in sport. Guided by egoistic interests, everybody in sport considers success an exceptional value. Success is associated not only with prestige, but in a lot of cases also with prosperity, popularity, higher social standing and so on. If people pursue success in accordance with current norms, this is only because of different kinds of sanctions employed by the social control in sport. As soon as people notice a chance to make profit and are confident that breaking rules will not result in a penalty, they will take the risk, break the rules and head for their goal not the way the society and culture tells them to, but down a road that circumvents the law. Examples of the above include all kinds of bribery, intimidation of referees, various performance-enhancing drugs as well as prohibited techniques, strikes, holds in sport competition. 
Merton also remarked that deviation could be a result of the transmission of a deviant culture. This means that certain separate communities adopt their own systems of values, norms and corresponding behavioural patterns which contravene the norms that govern the rest of the society. This is the kind of deviation we are dealing with in sport. While it is an exaggeration to say that everybody is engaging in doping themselves and only few fall victim to such practices, this assertion gives quite an accurate picture. I have never heard an athlete speak a word of condemnation about others who were caught using performance-enhancing drugs. This is a misapprehension of solidarity in sport: "I shouldn't condemn somebody who was caught doping himself, because next time, it may happen to me".

Like in a modern society, anomy processes and deviation phenomena occur in sport at different intensity and different stages of development. Their presence in sport is a consequence of corrupt tendencies of human nature on the one hand and the inefficiency of social control mechanisms on the other. This particularly applies to informal and internal control that results from the socialisation process, including socialisation in sport.

Imperialism in sport

As proper as de Coubertin's "all sports and all nations" postulate was in its assumptions, carrying it out turned out to be impossible in the practice of the Olympic movement.

The fundamental criterion in the division of the world is that of affluence. Most recently, this has concerned the conflict between the wealthy North and the poor South and a clash between the civilization of opulence and the civilization of poverty. The same situation occurs in Olympic sport, where European and American disciplines constitute the majority of Olympic events, with just a few others originating from outside this culture and civilization. Impoverished countries are almost entirely dependent on rich countries which, in many cases, pay the participation costs for athletes from backward regions, in line with the principles of Olympic solidarity.

Sport is the arena of an imperial conquest the mechanisms of which have been described by the so-called theory of dependence. This theory asserts that the most talented athletes from poor countries migrate to rich countries, where under anything but excellent training conditions, they are provided with opportunities to take part in prestigious leagues and receive exceptionally fair money for it. Moreover, they face prospects of further advancement up the sporting and social ladders (Huntington 1968).

One could also describe the above as giving extremely talented individuals a chance to refine their special gift. It is true and could hardly be denied. However, the sight of the sports human capital migrating from poor countries to rich ones presents a totally different image of the situation, namely, poor countries get exploited of their individuals with exceptional talent in sport. This diminishes the sporting potential of premodern societies and increases that of modern countries. In the disguise of national sovereignty, peripheral countries undergo neo-colonial sports exploitation by countries which constitute centres of capitalist development.

\section{Sport after modernity}

Throughout its history, modernity has undergone profound transformations. Sociologists seek to capture these transformations by employing three different schemes of change interpretation: 
evolutional, cyclical and dialectical. Obviously, the changes also occur in sport which has gone through significant transformations since the days of de Coubertin.

Contemporary sport is a sort of mega-formal organisation, an immense international corporation which displays all phenomena and processes which take place in contemporary societies and cultures (Sztompka 2005).

The future of sport has already happened

Theoreticians who make explicit or implicit references to the evolutional scheme take the view that "the future has already happened". This means that certain tendencies in contemporary sport are already there in an embryonic or a slightly more mature form and in the future, they will manifest themselves much more prominently. This point of view arises from the acceptance of a linear course of history.

Under the above concept, a diagnosis of contemporary sport can extrapolate and anticipate the future shape of sport, or more precisely, the direction of its development. This primarily concerns decreasing or evening out the differences between the organisation of sport in individual countries and regions of the world. The point is to enable poor countries, whose poverty and backwardness extends beyond sport, to reach a development phase which, to a lesser or greater extent, is found in most modern countries. This approach is expressed in the concept of a post-industrial society, developed by Daniel Bell and Alain Touraine. It is a society of the future, supposed to embody all current trends in development, or "megatrends" in the terminology of John Naisbitt.

If we apply the reflections of Ralf Dahrendorf (1990) to sport, we can assert that the emphasis in sport will shift towards services in the future. In other words, the structure of production and employment will move from traditional industries to the wide sector of services such as trade, finance, administration, transport, telecommunications, education and so on. As a spectacle, sport will thus play an increasingly important role and gain more significance in the society of the future. This process will be further prompted by the transformation of modern societies into "information societies" which rely on computer data processing technologies, most notably the Internet as an interactive medium.

The significance of sport will increase as a result of the changing status of labour in the lives of humans coupled with the increasing amount of free time and self-fulfilment opportunities. More and more intensively, sport will manifest the tendency which Peter Drucker (1993) described as "a knowledge-based society". The production of material goods in sport will get pushed into the background and be replaced by nondescript production and processing of knowledge, the new central commodity in sport.

The return of sport to times gone by

At the other end of approaches to questions on the future shape of sport, there is the idea of a cycle. In a cycle, better and fuller identification of the aspects and consequences of transformations in sport gives the beginning to a nostalgic idea of a return to an idealised past. This trend has a large group of supporters among theoreticians and is also quite frequent among the public, in literature and journalism.

What underlies this way of thinking is a return to strong family traditions, a revival of local communities and social ties, a move away from secularisation to piety and from science and 
technology to mystical, magical and intuitive thinking, and the abandonment of materialistic consumerism in favour of higher needs and values connected with self-fulfilment and a better quality of life. Without a doubt, the ultimate, idealised land of sporting bliss is ancient Greece, eulogised by many journalists and researchers. Ancient Greece generated the archetype of the Olympic Games, which creates a harmonious whole from the ideals of intellectual, physical, social, moral and religious refinement, called paideia and kalokagathia (Miller 2006).

According to the American sociologist Ronald Inglehart (1990), modern societies are shifting towards post-materialist values, such as high quality of life, health, physical fitness, rich experience, intense sensations, social life and so on. This also entails a higher role and importance of sport as an element of culture, complete with its well-developed and highly conventionalised range of meanings and symbols.

Anthony Giddens (1990) takes the view that scientific progress, education, the growing importance of mass media and modern communication technologies, all of which are typical of modernity, lead to the emergence of a new kind of social consciousness, or new "reflectiveness", where people take a critical view of themselves, discern diverse threats and pathologies and undertake various measures to put a to stop such worrying trends.

The way of thinking described above may "save" contemporary sport, because the awareness of threats and the public pressure motivates various organisations and social movements to take action to remove such threats. Here is where Merton's idea of "self-destructive prophecies" finds application. Under this concept, the sporting community realises a "warning forecast" or a "gloomy vision" of the future of sport and thus becomes motivated to take preventive action and eventually disprove the vision.

An attempt at overcoming the past and the present

Let us now elaborate on the dialectical scheme in thinking about societies which makes direct references to Hegel and Marx. Under this approach, the past and the present can be overcome through a fundamental qualitative change, through the creation of something new.

The American intellectual Francis Fukuyama (1992) put a lot of hope in the collapse of the communist system in the Soviet Union and Eastern Europe. With regards to sport, the hopes could be linked to the marginalisation of politics and ideologies in the sporting culture. One could have been led to believe that once the two rival political blocs were gone, sporting celebrations would give priority to the values of cooperation, community, friendship, peace and harmonious development of societies and cultures. However, the way Fukuyama understood them, somehow neither "the end of ideology" nor "the end of history" are anywhere in sight. It soon turned out that the old divisions and conflicts only gave way to new ones, based on religion, economy as well as politics. Terrorism has emerged as a new phenomenon and while terrorist acts also occurred in the past, terror has nowadays assumed global proportions and taken on a more sophisticated form. As a result, instead of a merry meeting of trustful people who pursue their sporting passions, the Olympic Games have become events fraught with extreme risks. They mobilise powerful national and international forces which employ state-of-the-art police and military equipment to ensure security during sporting events.

The concept of postmodernism (Bauman 1995) differs significantly from the above, but it nevertheless represents the same trend of thought. According to representatives of postmodernism, there are no historical or social regularities which could be formulated as laws. What we are dealing with here is sui generis. The characteristic features of postmodernism include the deconstruction and 
"implosion" of traditional social, racial, economic, sexual and other hierarchies. According to postmodernists, consumer objects and goods fully dominate over humans who lose their subjectivity, while interpersonal relations degenerate. The law and order of the present are supposed to be replaced with some nondescript hyperreality.

The postmodernist vision of sport is hard to imagine, although even today we can actually see some of its elements in the practice of sport. For example, economics and material resources have played an increasingly important role in the organization of sport, while sport itself is becoming increasingly oriented towards consumerism, pursuit of excitement and sensations, hedonism and style. Sport is becoming part of the omnipotent influence of the media and modern forms of mass communication. Another example are phenomena which presage anomy, that is, the disintegration of a certain axionormative order which is necessary for the appropriate evaluation and reception of a sporting spectacle.

\section{REFERENCES}

Anderson, B. (1997). Wspólnoty wyobrażone /Imagined Communities/. Cracow: Znak.

Bauman, Z. (1995). Wieloznaczność nowoczesności - nowoczesność wieloznaczności /The Ambiguity of Modernity - The Modernity of Ambiguity/. Warsaw: PWN.

Comte, A. (1973). Rozprawa o duchu filozofii pozytywnej /Dissertation on the Spirit of Positive Philosophy/. Warsaw.

Dahrendorf, R. (1990). The Modern Social Conflict. Berkeley: The University of California Press.

Drucker, P. (1993). Post-Capitalist Society. New York: Harper.

Durkheim, E. (2000). Zasady metody socjologicznej /The Principles of the Sociological Method/. Warsaw: PWN.

Fromm, E. (1963). The Sane Society. London: Routledge\&Kegan Paul.

Fukuyama, F. (1992). The End of History and Last Man. New York: Free Press.

Giddens, A. (1990). The Consequences of Modernity. Cambridge: Polity Press.

Huizinga, J. (1985). Homo ludens. Zabawa jako źródto kultury /The Play as the Source of Culture/. Warsaw: Czytelnik.

Huntington, S. (1968). Political Order in Changing Societies. New Haven: Yale University Press.

Inglehart, R. (1990). Culture Shift in Advanced Industrial Society. Princeton: Princeton University Press.

Kosiewicz, J. (2007). Czy igrzyska olimpijskie są czymś więcej niż sportem. /Are the Olympic Games anything more than Sport?/. In J. Kosiewicz (Ed.) Społeczne i kulturowe wartości sportu /Social and Cultural Values of Sport/. Warsaw: AWF.

Krawczyk, Z. (Ed.) (1997). Encyklopedia kultury polskiej XX wieku. Kultura fizyczna, sport /The Encyclopaedia of the Polish Twentieth-Century Culture. Physical Culture, sport/. Warsaw: IK.

Lipiec, J. (1999). Filozofia olimpizmu /The Philosophy of Olympism/. Warsaw: Sprint.

Lipiec, J. (2007). Pożegnanie z Olimpia /A Farwell to Olympia/. Cracow: Fall.

Lipoński, W. (2001). Encyklopedia sportów świata, /The Encyclopaedia of Word Sports/. Poznań: Atena.

Maffesoli, M. (1996). Times of the Tribes. The Decline of Individualism in Mass Society. London: Sage.

Marks, K. (1966). Dzieła, /Works/. vol. 13, Warsaw: KiW.

Merton, R. (1996). Social structure and anomie. In P. Sztompka (Ed.) R. Merton on Social Structure and Science. Chicago: The University of Chicago Press.

Miller, S. (2006). Starożytni olimpijczycy /Ancient Olympic Athlets/. Warsaw: PiW. 
Pawłucki, A. (2003). Podmiot olimpizmu wobec prowokacji ponowoczesności. /The Subject of Olympism towards the Provocation of Modernity/. In Z. Dziubiński (Ed.) Społeczny wymiar sportu /The Social Dimension of Sport/. Warsaw: SALOS RP.

Sztompka, P. (2005). Socjologia. Analiza społeczeństwa /Sociology. The Analysis of Society/. Cracow: Znak.

Tonnies F. (2008). Wspólnota i stowarzyszenie /Community and Association/. Warsaw: PWN.

Weber, M. (1975). Trzy czyste typy prawomocnego panowania/Three Types of Legitimate Rule/. In W. Derczyński, A. Jasińska-Kania, J. Szacki (Ed.) Elementy teorii socjologicznych. Materiaty do dziejów wspótczesnej socjologii zachodniej /The Elements of Sociological Theories. Maerials for the History of Contemporary Western Sociology/. Warsaw: PWN.

Weber, M. (2002). Gospodarka i społeczeństwo. Zarys socjologii rozumiejącej /Economy and Society. The Outline of the Understaning Sociology/. Warsaw: PWN.

Zuchora, K. (1996). Dalekie i bliskie krajobrazy sportu /Distant and Close Landscapes of Sport/. Warsaw: WSiP.

Żukowska, Z. (Ed.) (1996). Fair play, sport, edukacja. /Fair play, sport, education/. Warsaw: PTNKF. 